DOI 10.37882/2223-2982.2021.06.02

\title{
ОСОБЕННОСТИ ЛИЧНОСТНО-ПРОФЕССИОНАЛЬНОГО САМООПРЕДЕЛЕНИЯ ДЕТЕЙ С ОГРАНИЧЕННЫМИ В0ЗМОЖНОСТЯМИ ЗДОРОВЬЯ
}

\section{FEATURES OF PERSONAL AND PROFESSIONAL SELF-DETERMINATION OF CHILDREN WITH DISABILITIES}

\section{Badashkeev \\ M. Badashkeeva \\ N. Klementyeva \\ N.Sodnomova}

Summary: In this study, we tried to raise an urgent problem today, every year in rural schools, the number of special children increases, who in the future, as well as everyone, must make a choice of life and professional path. The current reality of Russian villages is characterized by global crisis phenomena in the socio-economic sphere, this situation is directly related to the coronavirus pandemic and global adult unemployment. Purpose: Development of personal and professional self-determination of children with disabilities. Methods: The main diagnostic tools in the course of the ascertaining and control experiments were the author's package of diagnostics developed on the basis of scientific research by G.V. Rezapkina, the study was conducted in the framework of individual consultation conversations, the subjects were offered adapted questionnaires containing fifteen statements to identify the level of formation of personal and professional self-determination of students with disabilities. Results: A program of professional orientation and professional tests, as well as a system of traditional activities implemented jointly with parents and social partners of the school, has been developed. Conclusions: The empirical study identified the most effective ways to develop personal and professional self-determination of children with disabilities. In this paper, we consider the variety of different theoretical positions on the studied problems regarding the individual development of rural schoolchildren with disabilities. The authors ' attention is focused on the joint psychological and pedagogical interaction with parents within the framework of the school of parental support "Tuya". This pedagogical imperative allows us to largely neutralize the negative socioeconomic factors that lead to a certain ambiguity among students with disabilities in choosing their future profession, as well as disinterest in working in rural areas.

Keywords: personal and professional self-determination; development; professional tests; parental support; children with disabilities; educational environment.
Бадашкеев Михаил Валерьевич к.n.н., педагог-психолог, МБОУ «Тарасинская СОШ», Иркутская область, n. Бохан

badashkeevm@mail.ru

Бадашкеева Марина Александровна Заместитель директора по ВР, ГБПОУ ИО «Боханский педагогический колледж им. Д. Банзарова», Иркутская область, п. Бохан

Климентьева Наталья Николаевна к.nсх.н., доцент, ФГБОУ ВО «Бурятский государственный университет им. Доржи Банзарова», г. Улан-Удэ Содномова Надежда Бадма-Цыреновна к.п.н., ФГБОУ ВО «Бурятский государственный университет им. Доржи Банзарова», г. Улан-Удэ

Аннотация: В данном исследовании мы постарались поднять актуальную проблему на сегодняшний день, с каждым годом в сельских школах увеличивается число особых детей, которые в будущем также как и все должны произвести выбор жизненного и профессионального пути. Современная действительность российских сел характеризуется глобальными кризисными явлениями в социально-экономической сфере, данное положение напрямую связано с пандемией коронавируса и глобальной безработицей взрослого населения. Цель: Развитие личностно-профессионального самоопределения детей с ограниченными возможностями здоровья. Методы: Основным диагностическим инструментарием в ходе констатирующего и контрольного экспериментов был авторский пакет диагностик, разработанный на основе научных изысканий Г.В. Резапкиной, исследование проводилось в рамках индивидуальных консультационных бесед, испытуемым предлагались адаптированные анкеты, содержащие пятнадцать утверждений для выявления уровня сформированности личностно-профессионального самоопределения обучающихся с ограниченными возможностями здоровья. Результаты: Разработана программа профессиональной ориентации и профессиональных проб, а также система традиционных мероприятий, реализуемых совместно с родителями и социальными партнерами школы. Выводы: В ходе эмпирического исследования были определены наиболее эффективные пути развития личностно-профессионального самоопределения детей с ограниченными возможностями здоровья. В данной работе мы рассматриваем многообразие различных теоретических позиций по исследуемой проблематике относительно индивидуального развития сельских школьников с ограниченными возможностями здоровья. Внимание авторов сконцентрировано на совместном психолого-педагогическом взаимодействии с родителями в рамках школы родительского сопровождения «Туя». Данный педагогический императив позволяет в значительной степени нейтрализовать негативные социально-экономические факторы, которые приводят к определенной неясности у обучающихся с ОВ3 в выборе будущей профессии, а также незаинтересованностью работать на селе.

Ключевые слова: личностно-профессиональное самоопределение; развитие; профессиональные пробы; родительское сопровождение; дети с ограниченными возможностями здоровья; образовательная среда. 
На современном этапе развития Российского образования и педагогической науки широко обсуждаются и анализируются проблемы развития личностно-профессионального самоопределения, что в принципе говорит о недостаточном просвещение молодежи с ограниченными возможностями здоровья путей самореализации в условиях современного села. На сегодняшний день данная проблема является очень актуальной, поскольку интеллектуальная деградация подрастающего поколения приобретает катастрофический характер. Переход Российской системы образования на инклюзивную модель образования, что подразумевает гуманное принятие детей и молодежи с ограниченными возможностями здоровья, а также права на общее образование, профессиональное образование, профессиональную самореализацию, полноценную интеграцию в современном обществе[1].

На наш взгляд подрастающему поколению с ограниченными возможностями здоровья (далее ОВ3) намного сложнее определится с выбором жизненного пути, чем обычной молодежи. Процесс личностно-профессионального самоопределения детей с ОВ3 значительно сложнее и многограннее, поскольку интеллектуальные, психофизиологические, физические возможности во многом ограничивают трудовую, а в будущем профессиональную деятельность. Мы в нашем исследовании основной упор производим на реальное, адекватное видение собственных возможностей в выборе профессионального пути, что в принципе является основополагающей успешного развития личностно-профессионального самоопределения обучающихся с ОВЗ. В следствии чего нами разработана программа профессиональных проб и программа психолого-педагогической поддержки с учетом индивидуальных возможностей обучающихся с ОВ3 [6].

В программах отражены основные теоретические воззрения С.Н. Чистяковой «профессиональное самоопределение как процесс формирования позиции личности в отношении себя как субъекта профессиональной деятельности» $[12$, с. 120], О.В. Бобковой, А.В. Ереминой «что профессиональный выбор молодых людей с ОВ3 должен осуществляться в зависимости от индивидуальных способностей и возможностей, что позволит более успешную профессиональную адаптацию и минимальную напряженность функциональных систем организма» $[7$, с. 90].

Для решения практико-ориентированных задач нам близки позиции Р.А. Афанасьевой, О.В. Кучергиной, Е.А. Французовой, О.В. Щелкуновой, А.М. Щербаковой, Е.Р. Ярская-Смирнова, которые отражаются в программе психолого-педагогической поддержки и программе профессиональной ориентации «На пути к звездам», где во главу угла ставятся индивидуальные возможности обучающихся с ОВ3 $[2,8,11,13,14]$. Так же мы опираемся на мнение зарубежных ученых M. Demirbağ, S. Kingir, A. Pipere, M. Veisson, I. SalÓte, которые считают, что «индивидуально-личностные особенности детей с ОВЗ приводят к определенным трудностям, что в принципе негативно сказывается на процессе развития выбора жизненного пути» $[15,16]$.

Таким образом, можно отметить, что современные ученые практики как отечественные, так и зарубежные склоняются к мнению о целенаправленной психолого-педагогической подготовке обучающихся с ОВ3. Мы полностью поддерживаем данное мнение и поэтому в разрезе мероприятий инновационного проекта «Разработка и реализация комплекса сетевых образовательных программ профессиональных проб для детей и молодежи $\mathrm{MO}$ «Боханский район», мы реализуем семь программ, но для обучающихся с ОВЗ были определены три направления: Мать Земля (агроном, землеустроитель, охотовед, лесник); Железный человек (инженер-механик, водитель автотранспортного средства, тракторист); Шэдитэ ханза - Волшебный сундучок (швея, продавец, парикмахер, мастер маникюра) [5, с. 65].

В данной работе мы совместно с родителями обучающихся с ОВ3 проектируем созидающую образовательную среду, которая в значительной степени повышает эффективность процесса развития личностно-профессионального самоопределения обучающихся с ОВ3 $[9,10]$. В рамках реализации психолого-педагогической поддержки личностно-профессионального самоопределения обучающихся с ОВ3, представлены в виде школы родительского сопровождения «Туя», это название выбрано неслучайно и несет глубокий философский смысл. Туя - «вечно зеленое хвойной дерево» - символ вечной жизни; Туй - с татарского языка «свадьба» - начало новой жизни; Туяа - с бурятского языка - «заря» - прекрасное таинство. Объединяя все значения воедино мы видим концептуальную основу иного психолого-педагогического воздействия на процесс развития личности[5, с. 68].

Таким образом, проведенное нами исследование выявило положительную динамику развития личностно-профессионального самоопределения обучающихся с ОВ3, что в принципе говорит об эффективном взаимодействии школы с родителями. Данные мероприятия обеспечили более осознанный профессиональный выбор и в последующем успешную профессиональную самореализацию. Также на наш взгляд реализация профессиональных проб в условиях сельской школы позволяет повысить эффективность процесса развития личностнопрофессионального самоопределения обучающихся с OB3. 


\section{ЛИТЕРАТУРА}

1. Положение инвалидов [Электронный ресурс] // Федеральная служба государственной статистики. Москва, 2015. Режим доступа: http://www.gks.ru/wps/ wcm/connect/rosstat_main/rosstat/ru/statistics/population/disabilities/ (дата обращения: 15.10.2018).

2. Афанасьева Р.А. Качество жизни и профессиональное самоопределение лиц с ограниченными возможностями жизнедеятельности в условиях семьи / Р.А. Афанасьева, В.И. Карпушенко // Специальное образование. - 2016. - № 2 (42). - С. 94 - 104.

3. Бадашкеев М.В. Пути педагогизации образовательного пространства современного села [Текст] статья / М.В. Бадашкеев // Педагогический журнал. Москва, 2016. № 3. С. - 175-185.

4. Бадашкеев М.В. Развитие личности старшеклассников в условиях сельской школы [Текст] статья / М.В. Бадашкеев // Педагогический журнал. - Москва, 2017. №1B. С. - 442-449.

5. Бадашкеев М.В. Особенности профессиональной ориентаций обучающихся с ограниченными возможностями здоровья в условиях современной сельской школы [Текст] статья / М.В. Бадашкеев // Педагогический ИМИДЖ. Иркутск., 2019. № 1. С. 57-69

6. Бедерханова В.П. Становление личностно-ориентированной позиции педагога: автореф. дис. ... д-ра пед. наук: 13.00.01, 19.00.07. Краснодар, 2002. 47 с

7. Бобкова 0.В., Ермина А.В. Модель профориентационной работы с учащимися старших классов, имеющими ограниченные возможности здоровья и инвалидность // Современные наукоемкие технологии. - 2017.-№5. - С. 89-93; URL: http://top-technologies.ru/ru/article/view?id=36674 (дата обращения: 08.10.2018).

8. Кучергина О.В., Шелкунова О.В. Осуществление инновационной деятельности в условиях специальной (коррекционной) школы: нормативно-правовой аспект: учеб. пособие / О.В. Кучергина, О.В. Шелкунова. - Иркутск: Изд-во ИГУ, 2017.- 131 с.

9. Организация работы по профориентации и профадаптации детей-инвалидов и лиц с ОВЗ: учебно-методический комплект / [сост. Г.В. Резапкина]; Минво образования Респ. Коми, Коми респ. ин-т развития образования. - Сыктывкар: КРИРО, 2014. - 48 с.

10. Резапкина Г.В. Психология и выбор профессии: программа предпрофильной подготовки. Учебно-методическое пособие для психологов и педагогов. Москва, Генезис, 2005. - 208 с.

11. Французова Е.А. Профессиональное самоопределение обучающихся в условиях профориентационной работы // Молодой ученый. - 2017. - №39. - С. 76 79. - URL https://moluch.ru/archive/173/45747/ (дата обращения: 07.10.2018).

12. Чистякова С.Н. Профессиональное самоопределение обучающихся: проблемы и пути решения // Профессиональное образование в России и за рубежом. 2015. № 2 (18). С. 118-122.

13. Щербакова, А.М. Проблемы трудового обучения и профессиональной подготовки учащихся вспомогательной школы // Дефектология. 1996. № 4. С. $24-28$

14. Ярская-Смирнова, Е.Р. Инклюзивное образование детей-инвалидов / Е.Р. Ярская-Смирнова, И.И. Лошакова // Социологические исследования. - 2003. № 5. - C. $100-106$.

15. Demirbağ M., Kingir S. Promoting pre-service science teachers' conceptual understanding about boiling by dialogic teaching. Journal of Baltic Science Education, Journal of Baltic Science Education, 16(4), Continuous. presented at the August/2017. Retrieved from http://oaji.net/articles/2017/987-1503904739.pdf

16. Pipere A., Veisson M., SalÓte I. Developing Research in Teacher Education for Sustainability: Journal of Teacher Education for Sustainability, vol. 17, no. 2, pp. 5ñ43, 2015. D0l: 10.1515/jtes-2015-0009

(c Бадашкеев Михаил Валерьевич (badashkeevm@mail.ru), Бадашкеева Марина Александровна, Климентьева Наталья Николаевна, Содномова Надежда Бадма-Цыреновна.

Журнал «Современная наука: актуальные проблемы теории и практики» 